\title{
Glycogenesis and Glycolysis in the Liver from Congenital Galactosemia
}

\author{
By \\ Keiya Tada \\ From the Department of Pediatrics, Faculty of Medicine, Tohoku \\ University, Sendai; Director: Prof. Ts. Arakawa \\ (Received for publication, February 14, 1964)

\begin{abstract}
Glycogensis and glycolysis in the liver from a galactosemic patient were investigated. The activity of glycogenesis in galactosemic liver showed a significantly low level as compared with that in control livers, while there was no remarkable difference in the activity of glycolysis between the patient's and control livers. It was suggested that the decrease in glycogensis in galactosemic liver was due to inhibitory effect of galactose-1-phosphate on phosphoglucomutase process.
\end{abstract}

Congenital galactosemia is an inborn error of metabolism due to a defect of galactose-1-phosphate uridyl transferase.

It has been generally postulated that this enzyme defect results in an accumulation of galactose-1-phosphate (Gal-1-P) which may cause cellular injury. However, little is known about secondary derangement in cellular metabolism caused by the primary enzyme defect.

The purpose of the present study is to investigate glycogen metabolism, which is closely related to galactose metabolism, in the liver of congenital galactosemia.

\section{METHODS AND MATERIALS}

A liver specimen was biopsied from a patient with congenital galactosemia whose diagnosis was confirmed by galactose tolerance test and Schwarz's test'1). As controls, surgical patients without liver involvement were subjected to liver biopsy. Immediately after the removal of liver specimens, the tissue slices were prepared at $0^{\circ} \mathrm{C}$. Each slice was put into incubation flasks of the Warburg manometer under the conditions shown in Table I.

The activity of glycolysis in the liver was investigated by manometric determination of lactic acid produced for two hours at $37^{\circ} \mathrm{C}$ under anaerobic 
TABLE I. Experimental Conditions

\begin{tabular}{|c|c|c|}
\hline & Glycolysis & Glycogenesis \\
\hline In cap & $\begin{array}{l}\text { K.R.B.* } 2.0 \mathrm{ml} \\
\text { Slice }\end{array}$ & $\begin{array}{l}\text { K.R.B. } 2.0 \mathrm{ml} \\
\text { Slice }\end{array}$ \\
\hline Side & Glucose $\begin{array}{r}0.2 \mathrm{ml} \\
(10 \mathrm{mg})\end{array}$ & $\begin{array}{l}\text { Glucose } 0.2 \mathrm{ml} \\
\quad(10 \mathrm{mg}) \\
\mathrm{C}^{14} \text {-Glucose } 0.1 \mathrm{ml}(2 \mu \mathrm{c})\end{array}$ \\
\hline Atmosphere & $95 \% \mathrm{~N}_{2}, 5 \% \mathrm{CO}_{2}$ & $95 \% \mathrm{~N}_{2}, 5 \% \mathrm{CO}_{2}$ \\
\hline Time (h.) & 2 & 1 \\
\hline Temperature & $37^{\circ} \mathrm{C}$ & $37^{\circ} \mathrm{C}$ \\
\hline Determination & Lactic acid & Radioactivity in glycogen fraction \\
\hline
\end{tabular}

* Krebs-Ringer-bicarbonate solution

condition.

The activity of glycogenesis in the liver was investigated by determining isotopically the conversion rate of $\mathrm{C}^{14}$-labeled glucose to glycogen. The incubation was carried out for one hour at $37^{\circ} \mathrm{C}$ under the anaerobic condition. At the end of the incubation, the glycogen fraction was isolated from the reaction mixture by Abder-Akler's method ${ }^{2}$. The radioactivity in the glycogen fraction was counted by a gas flow counter with the scaler of Radiation Counter Aloka DC- 5 .

\section{RESULTS}

Table II showed the results of in vitro activity of glycolysis in the livers from the patient and control subjects. The activity of glycolysis in galactosemic liver was found to be within control level.

Table III showed the results of in vitro activity of glycogenesis in the livers from the patient and control subjccts. The activity of glycogenesis was of significantly low level in the patient's liver as compared with that in control livers.

TABLE II. Activity of Glycolysis in the Livers from Patient with Congenital Galactosemia

\begin{tabular}{l|c|c} 
& Patient & Controls \\
\hline Glycolysis & & 16.9 \\
$\mathrm{Q}_{\mathrm{CO}_{2}}^{\mathrm{N}} \mu 1 \mathrm{CO}_{2} / \mathrm{h}$. & & 35.2 \\
& 28.9 & 18.6 \\
& & 42.0
\end{tabular}

Note: Figures are given as values per $1 \mathrm{mg}$ of nitrogen in the liver. 
TaBLe III. Conversion of $\mathrm{C}^{14}$-Glucose to Glycogen by the Liver from a Patient with Congenital Galactosemia

\begin{tabular}{l|c|c|c|c}
\hline & $\begin{array}{c}\text { Recovered in the } \\
\text { glycogen fraction } \\
(\mathrm{cpm})\end{array}$ & $\begin{array}{c}\text { Wet weight of } \\
\text { liver slice } \\
(\mathrm{mg})\end{array}$ & $\begin{array}{c}\text { The content of } \\
\text { nitrogen in } \\
\text { liver slice } \\
(\mathrm{mg})\end{array}$ & $\begin{array}{c}\text { Counts in the glyco- } \\
\text { gen fraction per } \\
\text { mg of nitrogen in } \\
\text { liver slice }\end{array}$ \\
\hline Patient & 195 & 80 & 1.28 & 152 \\
Controls & 331 & 85 & 1.25 & 265 \\
& 513 & 90 & 1.92 & 267 \\
& 790 & 88 & 1.67 & 473 \\
& 581 & 92 & 1.51 & 385
\end{tabular}

Note: Each flask initially contained $135,000 \mathrm{cpm}$ of labeled glucose.

\section{DISCUSSION}

It is reasonable to presume that Gal-1-P accumulates in the tissue of galac- tosemic patient because of defect of Gal-1-P uridyl transferase. In fact, Schwarz et $a l .^{3)}$ found the accumulation of large amounts of Gal-1-P in erythrocytes of patients with galactosemia both in vivo and in vitro. These observations were confirmed by other investigators ${ }^{4,5)}$. The accumulation of Gal-1-P in the liver of galactosemic patient was demonstrated by Tada ${ }^{6}$.

Such an excessive accumulation of Gal-1-P in the tissue is supposed to be responsible for various manifestations of this particular disorder through the injurious effect of Gal-1-P for cellular metabolism ${ }^{6,7)}$. It is, however, not fully understood how Gal-1-P affects cellular metabolism. The possible role of Gal-1-P in pathogenesis of the disease has been postulated by the recognition of the in vitro inhibition on some enzyme systems by Gal-1-P' ${ }^{8)}$. According to Najjar and Ginsburg8), Gal-1-P has in vitro an inhibitory effect on phosphoglucomutase which

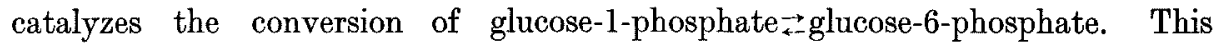
kind of inhibition could be reasonably expected as an instance of competitive inhibition arising from a very slight structural difference between glucose-1phosphate and galactose-1-phosphate.

The present results, a decreased activity of glycogenesis in galactosemic liver, might be explained by inhibitory effect on phosphoglucomutase by Gal-1-P accumulated in the liver.

Since phosphoglucomutase process is reversible, it is possible that glycogenolysis may be also interfered by Gal-1-P. Such a disturbance in synthesis and breakdown of glycogen secondarily due to Gal-1-P accumulation may play a role for cellular damage in this particular disorder.

\section{Literature}

1) Schwarz, V. \& Holzel, A., Lancet, 1958, 1, 24.

2) Abder-Akler, M. \& Smith, F., J. Amer, chem. Sac., 1951, 73, 994. 
3) Schwarz, V. Golberg, D., Komrower, G.M. \& Holzel, A., Biochem. J., 1956, 62, 34.

4) Tada, K. Akabane, J. \& Yokoyama, M., Tohoku J. exp. Med., 1962, 77, 400.

5) Donnel, G.N. Bergren, W.R., Perry, G. \& Koch, R., Pediatrics, 1963, 31, 802.

6) Tada, K., Tohoku J. exp. Med., 1962. 78, 1.

7) Isselbacher, K.J., The Metabolic Basis of Inherited Disease, edited by J. B. Stanbury et al., McGraw-Hill Book Company, New York, 1960, p. 208.

8) Sidbury, J.B., Molecular Genetics and Human Disease, edited by L.I. Gardner, Charles C. Thomas Publishers, Springfield, Illinois, 1961, p. 61. 